\section{Response of three waxy corn (Zea mays L. Var. Ceratina Kulesh) varieties and various planting date of intercropped groundnut (Arachis hypogaea L.) in dry field}

\author{
Kristono Y. Fowo, ${ }^{1}$ Nur Edy Suminarti, ${ }^{2}$ \\ Agus Suryanto 2 \\ ${ }^{1}$ Postgraduated program of Plant \\ Science Department, ${ }^{2}$ Department of \\ Agronomy, Faculty of Agriculture, \\ University of Brawijaya Malang, \\ Indonesia
}

\begin{abstract}
The research aims to determine the combination of waxy corn variety and planting date on the growth and yield of waxy corn in an intercropping system of corn and groundnut (Arachis hypogaea L.). The experimental design is a split-plot with the main plot consisting of waxy corn varieties (local variety; Uri variety and Binte Pulu variety and the sub-plot consisting of the alternate crop planting date. Three replications are performed. Data collection is done destructively. The $\mathrm{F}$ test at $5 \%$ is used to examine the effect of treatments, while differences across treatments are based on the LSD at 5\%. Research results show an interaction between the waxy corn variety and planting date on the growth parameter. There is an improved yield from the local variety planted 15 days before the groundnut planting date, as well as from the Uri variety planted both simultaneously with, and also 15 days before, the groundnut planting date, with maximum yields of 2.99 , 2.75 and 2.69 ton ha- ${ }^{1}$, respectively.
\end{abstract}

\section{Introduction}

Waxy corn (Zea mays L.) is one of the main food sources for the people of Nusa Tenggara Timur (NTT), East Indonesia. However, at 2.2-2.5 (ton ha- ${ }^{1}$ ), the production of waxy corn as the main food source in NTT is low compared to the national yield of 57 (ton ha- $\left.{ }^{1}\right){ }^{1}$ Problems contributing to the low yield include improper variety selection, as well as the cultivation technique, which is unsuitable for the predominating dry land agro-ecosystem in NTT.

In dry fields, improving the corn yield is challenged by water supplies, the rainy season in the dry land of Indonesia only lasts for 45 months, with uneven distribu- tion. Thus, with water the main limiting factor in dry land farming, ${ }^{2}$ any implemented strategy must consider water use efficiency. This can be approached through the planting arrangement pattern known as intercropping. $^{3}$

Intercropping is a planting technique that involves growing two or more crop species simultaneously, or in a staggered arrangement, in the same field. ${ }^{4}$ The cover crop, or alternate crop, can improve physical soil characteristics, add nitrogen $(\mathrm{N})$ (in the case of legumes), suppress weed growth, reduce nutrient leaching and erosion, and control water loss that occurs through evaporation. 5 ,6 The yield advantages of intercropping are primarily determined by the combination of the companion crops, as well as the planting date of the alternate crop, which can suppress competition between the two species. Therefore, an appropriate alternate crop planting date arrangement is needed to achieve a high yield per field area and time unit.

In this study, it was critical that the varieties selected were suited to the agro-climatic condition in the Ende region of Indonesia and had a high yield potential, ensuring adequate food supply. The objective was to determine the combination of waxy corn variety (Z. mays L. var. ceratina Kulesh) and planting date on the growth and yield of waxy corn in an intercropping system of corn and groundnut (Arachis hypogaea L.) planted on dry land.

\section{Materials and Methods}

The research was conducted in December 2015 to May 2016 on the dry land of Wiwipemo village, Wolojita subdistrict, Ende Regency-NTT, East Indonesia at $\pm 988 \mathrm{~m}$ above sea level. The average daily temperature ranged between $20-35^{\circ} \mathrm{C}$.

The field experiment used a split-plot design with three repetitions. The main plot (V) consisted of three waxy corn varieties $\mathrm{V} 1$ = local variety; $\mathrm{V} 2$ = Uri variety, and V3 $=$ Binthe Pulu variety). The split-plot (T) consisted of the alternate crop (groundnut) planting date $(\mathrm{T} 1=$ corn planted 15 days after the groundnut planting date; T2 = corn and groundnut planted simultaneously, and $\mathrm{T} 3=$ corn planted 15 days before the groundnut planting date). The plant spacing was $75 \times 40 \mathrm{~cm}$ for waxy corn and $25 \times 20$ $\mathrm{cm}$ for groundnut. Data was collected destructively by removing two crop samples at each observation time, namely 30 , 45, 60 and 75 days after planting (DAP) treatment combination. The growth parameters evaluated included leaf area $\left(\mathrm{cm}^{2}\right)$ (length $\times$ width $\times$ constant $^{7}$ and total crop
Correspondence: Kristono Y. Fowo, Postgraduated program of Plant Science Department, Faculty of Agriculture, University of Brawijaya, Malang 65145, Indonesia.

E-mail: kristonoyf@gmail.com

Key words: Intercropping, planting date arrangement, dry field, alternate crop, waxy corn.

Acknowledgements: The authors thank Wiwipemo village, Wolojita subdistrict, Ende Regency-NTT and Brawijaya University for facilitate this research.

Contributions: KYF, AS, study conception and design, analysis and interpretation of data, drafting of manuscript, critical revision; NES, study conception and design, acquisition of data, analysis and interpretation of data, drafting of manuscript.

Conflict of interest: the authors declare no conflict of interest.

Funding: none.

Received for publication: 20 October 2017. Accepted for publication: 30 November 2017.

This work is licensed under a Creative Commons Attribution-NonCommercial 4.0 International License (CC BY-NC 4.0).

${ }^{\circ}$ Copyright: the Author(s), 2019

Licensee PAGEPress srl, Italy

International Journal of Plant Biology 2019; $10: 7459$ doi:10.4081/pb.2019.7459

dry weight (g) (oven-dried at $80^{\circ} \mathrm{C}$, until constant weight) The yield components included the ear weight without the klobot (dry corn husk) per crop sample (g); ear diameter $(\mathrm{mm})$, obtained by using calipers to measure the top, middle, and bottom of each ear yielded from each crop sample, followed by averaging the sum of these three parts; kernel weight per crop (g), acquired by using an analytical scale to weigh all the kernels yielded from each ear of the crop samples, and kernel weight (ton ha- ${ }^{1}$ ), acquired by calculating kernel dry weight yielded per harvest plot, which was then converted into harvest plot per hectare (HPPH) using the following formula. ${ }^{6}$

\section{HPPH $=$ Kernels' dry weight per harvest plot $\times 1$-hectare area} harvest plot area

The harvest index (HI) was obtained using the following formula: ${ }^{8}$

$\mathrm{HI}=$ Kernels' economic yield / Crop's total dry weight

The $\mathrm{F}$ test at $5 \%$ was used to determine 
the effect of treatments, while treatment differences were evaluated using the LSD at $5 \%{ }^{9}$

\section{Results}

\section{Leaf area}

Observation results at 75 hst (Table 1) showed that the maximum leaf area was obtained from the local variety planted both 15 days before, but also simultaneously with, the groundnut planting date. In contrast, the minimal leaf area was obtained from Binthe Pulu variety planted 15 days after the groundnut. The highest leaf area for Uri variety, corresponded to corn planted 15 days before the groundnut planting date. In general, changing the corn planting date affected the leaf area yielded from each waxy corn variety by as much as 38.60 $\left(1,267.40 \mathrm{~cm}^{2}\right)$ and $36.88 \%\left(1,177.89 \mathrm{~cm}^{2}\right)$ for the local variety; $17.89\left(447.92 \mathrm{~cm}^{2}\right)$ and $22.46 \%\left(562.15 \mathrm{~cm}^{2}\right)$ for Uri variety, and $21.64\left(408.88 \mathrm{~cm}^{2}\right)$ and $29.93 \%(632.38$ $\mathrm{cm}^{2}$ ) for Binthe Pulu variety.

Table 1 indicated that the waxy corn variety and the planting date might have different effects on the crop's morphological appearance, regarding the root, shape, leaf number, as well as leaf area. Therefore, substantial impacts on factors, such as light, water, nutrients, as well as growing space, which affect the crop growth and yield, could be expected.

\section{Crop total dry weight}

The total dry weight of a crop (total dry matter yield) reflects the crop's ability to use the environmental factors. Table 2 shows the waxy corn crop total dry weight as a function of variety and planting date, respectively. Variety treatment showed a similar total dry weight pattern at all observation times, except at 60 hst. The local variety tended to produce crops having a relatively heavier total dry weight. The total crop dry weight reduced by a maximum $10.19(42.44 \mathrm{~g})$ and $11.40 \%$ (47.47 g) when the local variety was replaced with Uri and Binthe Pulu varieties, respectively. Regarding planting date treatment, the total dry weight pattern at each observation time was similar. Waxy corn planted 15 days before the groundnut planting date generat- ed the highest total crop's dry weight. However, when the planting date was changed to simultaneously with, and 15 days after, the groundnut planting date, the crop's total dry weight declined by a maximum of $13.54(59.93 \mathrm{~g})$ and $23.38 \%$ (103.48 g), respectively. A similar phenomenon occurred when the corn's planting date was changed from simultaneously with the groundnut, to 15 days after the groundnut planting date, which was as high as $11.38 \%$ (43.55 g).

\section{Harvest index}

The average HIs for the three corn varieties and the three alternates crop (groundnut) planting dates presented in Table 3 reveal that a higher HI was obtained from local and Uri varieties, which were both statistically similar. The lowest HI was obtained from Binthe Pulu variety. Regarding the groundnut planting date, the highest $\mathrm{HI}$ was obtained when planting was done 15 days before the groundnut planting date. However, when the planting date was changed from 15 days before the groundnut to simultaneously with, and 15 days after the groundnut planting date, it caused a

Table 1. Average leaf area per crop $\left(\mathrm{cm}^{2}\right)$ as the result of interaction between variety and corn planting date.

\begin{tabular}{|c|c|c|}
\hline Treatment combination & \multicolumn{2}{|c|}{$\begin{array}{l}\text { Average leaf area/crop }\left(\mathrm{cm}^{2}\right) / \text { observation age } \\
60 \text { hst } 75 \text { hst }\end{array}$} \\
\hline $\begin{array}{l}\text { Local (V1) } \\
\text { Waxy corn planted } 15 \text { days after ground nut (V1T1) } \\
\text { Waxy corn planted at the same time with ground nut (V1T2) } \\
\text { Waxy corn planted } 15 \text { days prior to ground nut (V1T3) }\end{array}$ & $\begin{array}{l}2313.38^{\mathrm{cd}} \\
2291.70^{\mathrm{cd}} \\
3183.43^{\mathrm{e}}\end{array}$ & $\begin{array}{l}2016.34^{\mathrm{b}} \\
3194.23^{\mathrm{d}} \\
3283.74^{\mathrm{d}}\end{array}$ \\
\hline $\begin{array}{l}\text { Uri (V2) } \\
\text { Waxy corn planted } 15 \text { days after ground nut (V2T1) } \\
\text { Waxy corn planted at the same time with ground nut (V2T2) } \\
\text { Waxy corn planted } 15 \text { days prior to ground nut (V2T3) }\end{array}$ & $\begin{array}{l}1736.49^{a} \\
2070.74^{b c} \\
2073.57^{b c}\end{array}$ & $\begin{array}{l}1941.13^{\mathrm{b}} \\
2055.36^{\mathrm{b}} \\
2503.28^{\mathrm{c}}\end{array}$ \\
\hline $\begin{array}{l}\text { Binthe Pulu (V3) } \\
\text { Waxy corn planted } 15 \text { days after ground nut (V3T1) } \\
\text { Waxy corn planted at the same time with ground nut (V3T2) } \\
\text { Waxy corn planted } 15 \text { days prior to ground nut (V3T3) }\end{array}$ & $\begin{array}{l}1415.75^{\mathrm{a}} \\
1827.21^{\mathrm{b}} \\
1780.33^{\mathrm{b}}\end{array}$ & $\begin{array}{l}1480.42^{\mathrm{a}} \\
2112.80^{\mathrm{b}} \\
1889.30^{\mathrm{b}}\end{array}$ \\
\hline LSD & 324.13 & 304.94 \\
\hline
\end{tabular}

Same letters show no significant difference based on LSD test at the level of 5\%.

Table 2. Average total dry weight of waxy corn crop in 3 varieties and 3 planting dates at 4 observational ages.

\begin{tabular}{|c|c|c|c|c|}
\hline \multirow[t]{2}{*}{ Treatment } & \multicolumn{4}{|c|}{ Total dry weight of crop (g) at observation age (hst) } \\
\hline & 30 & 45 & 60 & 75 \\
\hline \multicolumn{5}{|l|}{ Waxy corn variety } \\
\hline Local (V1) & $31.26^{\mathrm{b}}$ & $87.89^{b}$ & $129.50^{c}$ & 167.83 \\
\hline Uri (V2) & $28.59^{\mathrm{a}}$ & $78.56^{\mathrm{a}}$ & $110.39^{b}$ & 156.50 \\
\hline Binthe Pulu (V3) & $29.22^{\mathrm{a}}$ & $78.79^{\mathrm{a}}$ & $103.33^{\mathrm{a}}$ & 157.67 \\
\hline LSD 5\% & 1.66 & 2.58 & 6.24 & 3.00 \\
\hline \multicolumn{5}{|l|}{ Planting date of waxy corn } \\
\hline Waxy corn planted 15 days after ground nut (V1) & $25.15^{\mathrm{a}}$ & $69.29^{\mathrm{a}}$ & $98.28^{\mathrm{a}}$ & 146.44 \\
\hline Waxy corn planted at the same time with ground nut (V2) & $29.33^{\mathrm{b}}$ & $80.44^{b}$ & $111.50^{\mathrm{b}}$ & 161.44 \\
\hline Waxy corn planted 15 days prior to ground nut (V3) & $39.59^{\mathrm{c}}$ & $95.50^{\mathrm{c}}$ & $133.44^{\mathrm{c}}$ & 174.11 \\
\hline LSD 5\% & 1.81 & 2.55 & 3.32 & 1.84 \\
\hline
\end{tabular}

Numbers accompanied by the same letters at the same observation appears as do not significantly different under the same treatment based on LSD test at the level of $5 \%$. hst, days after planting. 
decline in the HI by as much as 4.92 and $16.39 \%$, respectively.

\section{Waxy corn}

Table 4 shows planting the local corn variety 15 days before the groundnut planting date resulted in the heaviest weight of ear without husk. In contrast, the lowest weight of ear without husk was obtained from Binthe Pulu variety irrespective of the waxy corn planting dates. In general, changing the corn planting date from 15 days before the groundnut planting date to both, at the same time, and 15 days after, the groundnut planting date led to a decrease in the weight of ear without husk obtained from each variety, which reached as much as $24.19(36.73 \mathrm{~g})$ and $28.05 \%$ (42.59 $\mathrm{g}$ ) for local variety, and 11.89 (15.44 g) and $19.42 \%$ (25.22 g) for Uri variety, respectively.

The highest ear diameter parameter was obtained from Uri variety planted the same date as the groundnut. In contrast, the lowest ear diameter was obtained when corn planting occurred 15 days after the groundnut planting date for Uri and local varieties, and for Binthe Pulu variety at all planting dates. Changing the waxy corn planting date led to a decrease in ear diameter yielded from each waxy corn variety by as much as 7.23 and $9.77 \%$ for the local variety, and 7.70 and $18.72 \%$ for Uri variety, when he planting date changed from simultaneously with, to 15 days before, and 15 days after, the groundnut planting date, respectively.

The kernel weight per crop and kernel weight per hectare (Table 4) showed similar patterns. Generally, the use of the three waxy corn varieties showed that the lowest kernel weight, both per crop and per hectare, were obtained from planting corn 15 days after the groundnut planting date, whereas, the heaviest came from the local variety plant ed 15 days before the groundnut planting date. Generally, changing the waxy corn planting date led to a decrease in the kernel weight, both per crop and per, by as much as 19.18 (18.32 g) and 29.74\% $(28.70 \mathrm{~g})$, respectively, for the local variety when the planting date was changed from 15 days before the groundnut planting date, to both at the same time, and 15 days after, the groundnut planting date. Regarding Uri and Binthe Pulu varieties, the decrease in kernel weight per crop and per hectare, occurred when the waxy corn planting date was changed from 15 days before, and at the same time as the groundnut planting date, to 15 days after the groundnut planting date. For kernel weight per crop, the decrease was, respectively, as high as 24.82 $(21.49 \mathrm{~g})$ and $27.26 \%$ (24.40 g) for Uri variety, and $13.36(10.21 \mathrm{~g})$ and $16.42 \%$ (13.01 g) for Binthe Pulu. For kernel weight per hectare, the decrease was, respectively, as high as 21.07 (0.63 ton) and 31.10\% (0.93 ton) for the local variety, $26.86 \%$ (0.73 ton) for Uri variety, and $15 \%$ (0.38 ton) for Binthe Pulu.

\section{Discussion}

The main function of a leaf is photosynthesis, leaf area differences between crops will affect the crop's photosynthetic rate and, thereby, carbohydrate (glucose) synthesis. ${ }^{10}$ Thus, the comparatively broader leaf area of the corn planted 15 days before the groundnut planting date, could be expected to have a relatively greater photosynthesis rate. ${ }^{11}$

Table 3. Average harvest index of waxy corn for the 3 varieties and 3 planting dates at harvest time (110 hst).

\begin{tabular}{lc} 
Treatment & Harvest index (HI) \\
Waxy corn variety & $0.62 \mathrm{~b}$ \\
Local (V1) & $0.61 \mathrm{~b}$ \\
Uri (V2) & $0.47 \mathrm{a}$ \\
Binthe Pulu (V3) & 0.03 \\
LSD 5\% & $0.51 \mathrm{a}$ \\
\hline Planting date of waxy corn & $0.58 \mathrm{~b}$ \\
Waxy corn planted 15 days after ground nut (V1) & $0.61 \mathrm{c}$ \\
Waxy corn planted at the same time with ground nut (V2) & 0.02 \\
Waxy corn planted 15 days prior to ground nut (V3) & \\
LSD 5\% &
\end{tabular}

Numbers accompanied by the same letters, on the same column, under the same treatment appears as not significantly different based on LSD test at the level of 5\%.

Table 4. Interaction between waxy corn and planting date towards average ear weight without husk, ear diameter, kernel weight per crop, and kernel dry weight (ton ha $\left.{ }^{-1}\right)$ at harvest time (110 hst).

\begin{tabular}{|c|c|c|c|c|}
\hline Treatment combination & $\begin{array}{l}\text { Kernel Ear (-) } \\
\text { husk/crop (g) }\end{array}$ & $\begin{array}{l}\text { Ear diameter } \\
(\mathrm{mm})\end{array}$ & $\begin{array}{c}\text { Kernel } \\
\text { weight/crop (g) }\end{array}$ & $\begin{array}{c}\text { Kernel } \\
\text { weight/ha (ton) }\end{array}$ \\
\hline \multicolumn{5}{|l|}{ Local (V1) } \\
\hline Waxy corn planted 15 days after ground nut (VIT1) & $109.22^{\text {cd }}$ & $38.80^{\mathrm{ab}}$ & $67.81^{\mathrm{a}}$ & $2.06^{\mathrm{a}}$ \\
\hline Waxy corn planted at the same time with ground nut (V1T2) & $115.08^{\mathrm{d}}$ & $39.89^{b}$ & $77.19^{\mathrm{b}}$ & $2.36^{\mathrm{b}}$ \\
\hline Waxy corn planted 15 days prior to ground nut (V1T3) & $151.81^{\mathrm{f}}$ & $43.00^{c}$ & $96.51^{\mathrm{d}}$ & $2.99^{\mathrm{d}}$ \\
\hline \multicolumn{5}{|l|}{ Uri (V2) } \\
\hline Waxy corn planted 15 days after ground nut (V2T1) & $106.64^{\mathrm{bc}}$ & $39.07^{\mathrm{ab}}$ & $65.11^{\mathrm{a}}$ & $1.99^{\mathrm{a}}$ \\
\hline Waxy corn planted at the same time with ground nut (V2T2) & $114.42^{\mathrm{d}}$ & $48.07^{\mathrm{d}}$ & $89.51^{\mathrm{c}}$ & $2.75^{\mathrm{c}}$ \\
\hline Waxy corn planted 15 days prior to ground nut (V2T3) & $129.86^{\mathrm{e}}$ & $44.37^{\mathrm{c}}$ & $86.60^{c}$ & $2.69^{c}$ \\
\hline \multicolumn{5}{|l|}{ Binthe Pulu (V3) } \\
\hline Waxy corn planted 15 days after ground nut (V3T1) & $93.44^{\mathrm{a}}$ & $38.25^{\mathrm{ab}}$ & $66.21^{\mathrm{a}}$ & $2.00^{\mathrm{a}}$ \\
\hline Waxy corn planted at the same time with ground nut (V3T2) & $99.64^{\mathrm{ab}}$ & $39.09^{\mathrm{ab}}$ & $79.22^{\mathrm{b}}$ & $2.38^{b}$ \\
\hline Waxy corn planted 15 days prior to ground nut (V3T3) & $96.81^{\mathrm{ab}}$ & $37.26^{\mathrm{a}}$ & $76.42^{b}$ & $2.38^{b}$ \\
\hline LSD & 9.61 & 2.19 & 7.00 & 0.21 \\
\hline
\end{tabular}

Numbers accompanied by the same letters, on the same column, under the same treatment appears as not significantly different based on LSD test at the level of $5 \%$. 
Total dry weight is the accumulation of organic compounds synthesized by the crop and is a result of photosynthesis in the leaf Gadner et al. (2003) stated that photosynthesis produces carbohydrates (glucose) that are accumulated in the form of a crop's dry matter. ${ }^{12}$

Therefore, carbohydrate-producing photo-synthesis cannot run perfectly. This will influence the generative growth. The quantity of stored carbohydrate will be directly pointed out by the harvest index value that describes the quantity of assimilating that can be allocated to the storage organ (seed). The higher the harvest index, the higher the yield to be earned. This is supported by Dordas (2009), stated that harvest index is an indication of how vegetative dry weight (biomass) is allocated to the seed at maturity period. ${ }^{13}$

The results suggest that planting waxy corn 15 days after the alternate crop of groundnut was unable to suppress the competition for environmental growth factors due to the limited root and canopy space since its initial growth. Al though over time, corn has higher morphology than groundnut, corn competes with groundnut for water, nutrients, and light since its initial growth. When the vegetative growth of a plant is low due to a lack of environmental factors (water, nutrients, and light) essential for growth its generative growth is directly affected.

In general, the success of intercropping depends not only on selecting the appropriate companion crop species but is also largely determined by the successful planting date arrangement. One of the requirements necessary for plants to be suitable for intercropping is that the alternate and main crop originate from different groups of crop. For instance, groundnut and corn were selected in the current study. Groundnut is a C3 crop that needs a relatively short light exposure and is suited for intercropping with corn, which is a C4 crop that needs full light exposure. ${ }^{14}$

\section{Conclusions}

Treatments of local waxy corn variety and groundnut, as the alternate crop, planted 15 days after the waxy corn planting date can increase various growth parameters of waxy corn compared to those of Uri variety for all planting dates.

Waxy corn planted 15 days before the groundnut planting date resulted in a $26.69 \%$ higher dry kernel weight compared to local waxy corn variety planted simultaneously with groundnut. For Uri variety, a higher dry kernel yield (ton ha- ${ }^{1}$ ) was obtained by planting 15 days before, or simultaneously with the groundnut planting date, which was as high as 2.69 and 2.75 (ton ha- $^{1}$ ), respectively, and $36.68 \%$ higher than waxy corn planted 15 days after the groundnut planting date.

\section{References}

1. Badan Pusat Statistik (BPS). Produksi Jagung Menurut Provinsi 2010-2014. Jakarta: Badan Pusat Statistik Indonesia; 2014.

2. Guritno B. Pola Tanam di Lahan Kering. Malang: UB Press; 2011.

3. Suminarti NE. Teknik Budidaya Tanaman Talas (Colocasia esculenta (L) Schott var. Antiquorum pada Kondisi Kering dan Basah. Master Disertation. Faculty of Agriculture, University of Brawijaya.

4. Francis C, Jons A, Wittler K, Goodman S. Strip cropping corn and grain legumes: a review. Am J Altern Agric
1986;1:159-64.

5. Kramberger B, Gselman A, Janzekovic $\mathrm{K}$, et al. Effects of cover crops on soil mineral nitrogen and on the yield and nitrogen content of maize. J Agron 2009;31:103-9.

6. Suminarti NE. Pengaruh Tingkat Ketebalan Mulsa Jerami pada Pertumbuhan dan Hasil Tanaman Talas (Colocasia esculenta (L) Schott var. Antiquorum. J Agron 2015;2:1-13.

7. Mokhtarpour HCB, Teh S, Sale G, et al. Non-destructive estimation of maize leaf area, fresh weight and dry weight using leaf length and leaf width. Int J Agric Biol 2010;5:19-26.

8. Sitompul SM, Guritno B. Analisis Pertumbuhan Tanaman. Fakultas Pertanian. Universitas Brawijaya. Yogyakarta: Gadjah Mada Press; 1995.

9. Hanafiah KA. Rancangan Percobaan Teori dan Aplikasi. Fakultas Pertanian. Universitas Sriwijaya Palembang. Jakarta: PT. Raja Grafindo Persada; 1991.

10. Prasetyo. Budidaya Kapulaga Sebagai Tanaman Sela Pada Tegakan Sengon. J. Ilmu Pertanian 2006;6:22-31.

11. Ai SN, Banyo Y. Konsentrasi Klorofil Daun Sebagai Indikator Kekurangan Air Pada Tanaman. J. Ilmiah Sains 2011;11:166-73.

12. Gardner FP, Pearce RB, Mitchell RL. Physiologi of Crop Plants. United States: Lowe State University; 2013.

13. Dordas C. Dry Matter Nitrogen and Phosphorus Acumulation, partitioning and remobilization as affected by $\mathrm{N}$ and $P$ fertilization and source-sink relations. Eur J Agron 2009;30:129-39.

14. Sitompul SM, Purnomo. Peningkatan Kinerja Tanaman Jagung dan Kedelai pada Sistem Agroforestri Jati dengan Pemupukan Nitrogen. J Agrosains 2004;6:79-83. 